\title{
On the Estimation of Cost of Equity using Industrial CAPM Approach
}

\author{
Hassan Raza1, Aijaz Mustafa Hashmi², Abdul Rashid ${ }^{3}$ \\ ${ }^{1}$ Assistant Professor, Faculty of Management Sciences, SZABIST Islamabad \\ ${ }^{2}$ Assistant Professor, Department of Management Science, NUML Islamabad \\ ${ }^{3}$ Associate Professor, International Institute of Islamic Economics, IIU Islamabad
}

\section{A B S T R A C T}

This paper is an attempt to empirically investigate the industrial risk premium and realized return relationship by extending hybrid CAPM of Bodnar, Dumas, and Marston (2004). The inclusion of the industry risk premium offers more sophisticated results. Fama and Macbeth (1973) methodology is applied to test this relationship. The results indicate that there is a positive and significant relationship of industry risk premium for Pakistan, India, and Brazil, whereas, it is insignificant for China, Russia, and South Africa. It is also seen that other risk premiums are insignificant for the said countries if industry risk premium is considered. The results also indicate that industry risk premium is only significant for those countries where the firms are mostly operated through the family business environment like Pakistan, India, and Brazil. This may lead to conclude that industry risk premium can be used as the agency cost of minatory shareholders and controlling shareholders. This study provides an insight for the global investors, FPI holders, local and global mutual fund manager, to incorporate this industry risk premium into the existing CAPM framework especially for the countries where business is managed as family environment.

Key Words: Cost of Equity, Industrial CAPM, Industrial Risk Premium

\section{INTRODUCTION}

After the emergence of the notion of portfolio management in the 1950s, various attempts have been made to measure the association between risk and return in the field of investment. Sharpe (1964) is the pioneer who work theoretically on the above lines and report that market's risk premium is the only risk factor to be accounted for expected return that leads to traditional capital asset pricing model. After this, much of work can be witnessed in this area in two different ways: firstly, in testing the validity of this model and secondly, in proposing a new model by using the same framework after adjustment 
of more risk factors. In the same lines, many studies subsequently validate CAPM empirically e.g. Black, Jensen, and Scholes (1972); Douglus (1968); (ES \& Antony, 2020); Fama and Macbeth (1973); Jones (1991), while other provide weak evidence e.g. Fama and French (1992); Pei (2019); Škrinjarić and Slišković (2020), whereas many other reject this model e.g. Musawa, Kapena, and Shikaputo (2020); Rashid and Hamid (2015); Urom, Chevallier, and Zhu (2020).

Every investment decesions comprises of different risk factors, and capital market theory provides the basic framework of how these risk factors can be converted to expected return. It also clarifies that only systamtic risk factors can be translated for this purpose. Past work can also be seen for the adjustment of more than one risk factor that affects the expected returns. Like Fama and French (1992) found that the adjustment of size and value factor into the existing CAPM that improve the explanatory power of the model, and the same results are reported by many other researchers across time and cross section. Yet, criticism can be seen in the use of these factors. According to Perold (2004), both size and value factors are not about risk at all. According to him, if size is a risk factor, then small firms combine themselves to form large firms. Likewise, the value effect is based on giving equal weight to small and large firms, which are already lying in capitalization-weighted value indexes. He concludes that till the actual risk attributes that underlies behind these factors have been identified, the explanatory power of the model is in doubt. So, if these factors cannot be termed as risk and cannot claimed for the extra return than question still remain that what are different systematic risk factors that can be claimed for the returns.

\section{LITERATURE REVIEW}

Past researches explain different systematic risk factors in this regards, However, common factors are global risk factor, emerging market risk factor, country risk factor, industry risk factor and project risk factor (Bekaert, Harvey, Lundblad, \& Siegel, 2016; Lessard, 1996). Researchers accommodated different risk factors while forming their capital asset pricing models. Solinik (1974); Stulz (1995) work on the world premium risk and develop Global CAPM, Mariscal and Lee (1993) introduce the country risk 
factor into the Global Model and develop Goldman Sachs' model, Bawa and Lindenberg (1977); Estrada (2002); Harlow (1991); Hogan and Warren (1974), work on the downside movement of beta and result in downside CAPM, Erb, Harvey, and Viskanta (1998); Godfrey and Espinosa (1996); Lessard (1996) work on both global and emerging market risk premium and develop new models for emerging markets, while Kayo, Martelanc, Brunaldi, and da Silva (2020) recommends to use multiple CAPM models to calculate the cost of equity for the energy companies.

Market integration literature shows that stock markets at country and global level are integrating with each other and this change can be seen in stock holding patterns, investment volumes, portfolio patterns and financial performance of both domestic and foreign firms. This opponent and proponent litrature of market integration and market isolation results the challenges for individual and institutional investors to value different types of assets. Most importantly, what are the risk factors that result in the increase and decrease assets' value and how these risk factors, i.e. industry specific risk factors, country specific risk factors and Global specific risk factors are incorporated in the prices of such assets that reflect their true intrinsic value? Some of them also argue to use single period CAPM or multiperiod CAPM to calculate the cost of the equity (Barinov, Xu, \& Pottier, 2020). It becomes difficult to estimate the accurate cost of equity without adjustment of these aforementioned factors thereby making it a challenging job for the entire world. A different view work on the stability of CAPM beta, and work on different CAPM for the calculation of cost of equity, found that adjustment of more factors into the existing model, improve the stability of the beta (Barinov et al., 2020).

Consequently, a new debate in this domain has been started for the estimation of cost of equity in developed and emerging markets. Due to variety of opinions in the estimation of cost of equity, along with high betas in emerging markets, various studies attempt to validate CAPM based models that originates two different schools of thoughts i.e. opponent and proponents. Proponents suggest the use of already developed CAPMs for the estimation whereas the opponents express their concerns on the estimation by highlighting the importance of new risk factors such as market volatility, industry risk, and country specific risk. Some of them also suggested, testing of the validity of the 
CAPM model using the high frequency data (Hollstein, Prokopczuk, \& Wese Simen, 2020).

Such progress has been achieved, offer a motivation to endure working for further adjustments of risk. Competitive environment of the participating company is explained by the industry risk. Industry related adjustments are often made in computations of cost of firm's capital. The user of CAPM considers industry risk as infused through the computation of Beta. However, while using buildup method, this has to be augmented in the shape of risk premium (Barad, 2011). Less empirical work can be traced subject to adjustment of industry risk premium into the CAPM. Lee, $\mathrm{Ng}$, and Swaminathan (2003) estimate the industry risk premium for 28 industries for the G-7 countries for the period of 1990 to 2000 . Their results indicate that industry premium varies industry-wise and timewise. Food, Real Estate, Chemicals, Publishing, and Utilities are reported lowest risk premium from $2 \%$ to $3.32 \%$, while Tobacco, Mining, Metals, Transport Equipment, and Paper are reported as high premium industry from $6.68 \%$ to $9.42 \%$. These results clearly indicate that industry risk premium is an integral part of estimating global cost of equity. Abuaf (2011) argue that estimation of industry betas yield more robust estimates than estimating company-specific betas. Further their study indicates that betas change considerably from one industry to the other but in those industry, betas do not vary significantly when measured over different time horizon.

Thus, this study hinges and deliberates upon examining the implication and operationalization of industry extended model in six emerging i.e. Pakistan, India, China, Brazil, Russia, and South Africa by keeping the backdrop to all issues related to market risk, industry risk and country risk. This would be a step forward for firms to estimate their equity financing cost by using industry, country and global risk premium.

The paper is structured as follows. After presenting the introduction in Section 1, Section 2 describes methodology and data. Section 3 presents the empirical results. Section 4 concludes the paper.

\section{RESEARCH METHODOLOGY}

The study extends the hybrid CAPM model as proposed by Bodnar et al. (2004). 
Their study suggests, while evaluating cost of equity for firms who are working in emerging market, two basic risk should be take care of, one is global risk and other is emerging market risk, but this study suggest to incorporate the industry risk premium which is also an important contribution as discuss earlier.

$E\left(R_{i}\right)=R_{f}^{G}+\beta_{i}^{G}\left(R_{M}^{G}-R_{f}^{G}\right)+\beta_{i}^{E M}\left(R_{M}^{E M}-R_{f}^{E M}\right)+\beta_{i}^{I N D}\left(R_{M}^{I N D}-R_{f}^{L}\right)$

$\beta_{i}^{G}$ : Beta of the security with respect to the Global market

$\beta_{i}^{E M}$ : Beta of the security with respect to the Emerging market

$\beta_{i}^{I N D}$ : Beta of the security with respect to the Local Industry

$\left(R_{M}^{G}-R_{f}^{G}\right)_{\text {Excess Global Market Return }}$

$\left(R_{M}^{\mathbb{E M}}-R_{f}^{\mathbb{E M}}\right)$ Excess Emerging Market Return

$\left(R_{M}^{M D}-R_{f}^{L}\right)$ Excess Industry Return

The present research utilizes, share prices on monthly basis, which have been attuned for stock dividends, splits as well as rights issues. The study has a sample from June to June, 2000 to 2017. Risk free rate of 3-month is utilized as a representation of the risk-free return. The data is extracted from DataStream for six emerging countries namely as Pakistan, Brazil, Russia, India, China, and South Africa. Inclusion of companies in the study is based upon the availability of approximately $90 \%$ of the market CAP and Total trading Volumes. Thus, the sample that has been selected is a decent representative of overall market. Morgan Stanly Composite Index Global is used as a proxy of Global market premium while MSCI-Emerging index is used as a proxy for emerging market premium.

For the construction of Industry index, study uses free float methodology in which stocks are weighted relative to their free float-adjusted market capitalization and then assigned an equal weight (i.e.1/N, where $\mathrm{N}$ is the number of Stocks) to each sector to drive on desired industry weighted index. The selection of the firms into the industry index is based on maximum sector approximation approach where index is calculated on all possible retrievable companies belonging to that sector and analyst believe this would be a good representation to capture the industrial risk premium (Pereiro, 2001). Further, 
level 4 Industry Classification Benchmark' (ICB) is used to classify firms into each industry.

Monthly stock returns of the stocks, as well as indices, are computed by $R_{\mathrm{t}}=\ln \left(\frac{p_{\mathrm{t}}}{p_{\mathrm{t}-1}}\right)$. The study makes utility of Fama-Macbath (1973) methodology of having cross sectional regressions on the recommendation of Cederburg and O'Doherty (2016), after deriving the values of time series systematic risk i.e. Beta for the testing of the simple risk and return connection in between the expected return and the fundamental systematic beta. This procedure makes application of 2 steps for authenticating the CAPM. In principal step, we generate the rolling beta utilizing 36-month windows and in subsequent step, these obtained betas values are regressed in cross-sectional ways against the average yield of stocks.

\section{RESULTS AND ANALYSIS}

Descriptive analysis for all stocks returns, industry premiums, global market premium and emerging market premiums is provided in Table 1 . The mean value of stock returns for emerging markets indicates that investor earns a maximum of 0.9 percent average monthly returns by investing in shares of Pakistan stock exchange, while Moscow stock exchange is proving the lowest -.1 percent return that rest of all during the sample period. Moreover, maximum fluctuations in earning can be seen in Bombay stock exchange that is about $21.3 \%$ per month, while the minimum fluctuations in earning are in Shanghai stock exchange of about $11.3 \%$.

Industrial mean and standard deviations for emerging markets indicate that one can earn maximum industrial return by investing in Pakistan and Bombay of about $1 \%$ per month, while again Moscow Stock exchnage offer lowest industrial return of about $.1 \%$ than all others. Stock fluctuations indicate that $17.7 \%$ which depicts that investment in stocks pertains high risk as compared to its return. Likewise, minimum return i.e. 44 percent and maximum return i.e. 518\% are reported in investment in stocks. On the other hand, value of PSX Market return is $1.4 \%$ monthly pertaining $8.6 \%$ volatility. It depicts that market movement is asymmetric in nature. Subsequently, in the range of $24 \%$ to - 
44.9\% market returns are being reported in the study. Returns of stocks are highly leptokurtic $($ Kurt $=92.624)$ and partially skewed $($ Skew $=1.266)$. PSX market returns are least leptokurtic in distribution shape $($ Kurt $=8.52)$ and negatively skewed $($ Skew $=-$ 1.239). Industry wise returns i.e. a proxy for industry market premium reports 1 percent on average return earned by an investor explaining $8.7 \%$ deviation. Prospective investor may earn maximum 144.7 percent monthly returns and may bear loss of 126.8 percent. These returns are highly leptokurtic in distribution shape (Kurt =42.091) along with nominal Skewness $($ Skew $=0.298)$.

\begin{tabular}{|l|c|c|c|c|c|c|}
\hline Table 1. Descriptive Analysis & Means & Std.Dev & Min & Max & Skew. & Kurt. \\
\hline Variables & 0.009 & 0.177 & -4.459 & 5.189 & 1.266 & 92.624 \\
\hline Pak-Stock Return & 0.01 & 0.087 & -1.268 & 1.447 & 0.298 & 42.091 \\
\hline Pak-Industry Return & 0.007 & 0.213 & -3.106 & 6.164 & 1.954 & 35.564 \\
\hline Bombay Stock Return & 0.01 & 0.107 & -0.825 & 0.819 & 0.249 & 7.088 \\
\hline Bombay Industry Return & 0.005 & 0.15 & -1.316 & 2.386 & 0.033 & 7.337 \\
\hline Shanghai Stock Return & 0.005 & 0.113 & -0.465 & 0.552 & -0.477 & 4.637 \\
\hline Shanghai Industry Return & 0.007 & 0.163 & -2.639 & 4.58 & 2.597 & 72.75 \\
\hline Brazil Stock Return & 0.003 & 0.1 & -2.126 & 1.381 & -3.071 & 89.417 \\
\hline Brazil Industry Return & -0.001 & 0.159 & -5.218 & 5.416 & 3.219 & 333.525 \\
\hline Moscow Stock Return & 0.001 & 0.085 & -1.157 & 1.128 & 0.774 & 22.315 \\
\hline Moscow Industry Return & 0.006 & 0.151 & -6.31 & 6.253 & 0.865 & 246.6 \\
\hline Johannesburg Stock Return & 0.009 & 0.066 & -0.633 & 0.676 & -0.033 & 11.041 \\
\hline $\begin{array}{l}\text { Johannesburg Industry } \\
\text { Return }\end{array}$ & 0 & & & & \\
\hline
\end{tabular}

Following results are obtained by Fama \& Macbeth (1973) cross sectional regression with industrial adjusted risk factor for each country.

\begin{tabular}{|l|c|c|c|c|c|c|}
\hline \multicolumn{1}{|c|}{ Table 2. Cross Sectional Regression } \\
\hline & Pak & India & China & Russia & South & Brazil \\
\hline Global Beta & 0.00301 & $0.00446^{* *}$ & -0.00185 & 0.00209 & -0.00466 & -0.00222 \\
\hline & $(0.0032)$ & $(0.0014)$ & $(0.0017)$ & $(0.0014)$ & $(0.0029)$ & $(0.0029)$ \\
\hline EMR Beta & $0.00734^{*}$ & $0.00255^{*}$ & 0.00207 & -0.00275 & $0.0109^{* * *}$ & 0.00114 \\
\hline & $(0.0031)$ & $(0.0014)$ & $(0.0013)$ & $(0.0022)$ & $(0.0041)$ & $(0.0052)$ \\
\hline IND Beta & $0.00324^{*}$ & $0.00466^{* *}$ & -0.00183 & -0.000327 & 0.00186 & $0.00215^{*}$ \\
\hline & $(0.0014)$ & $(0.0008)$ & $(0.0013)$ & $(0.0002)$ & $(0.0016)$ & $(0.0010)$ \\
\hline Constant & -0.00016 & $0.00211^{* *}$ & $0.00794^{* *}$ & - & - & - \\
\hline & $(0.0016)$ & $(0.0006)$ & $(0.0013)$ & $(0.0008)$ & $(0.0015)$ & $(0.0013)$ \\
\hline R-squared & 0.059 & 0.053 & 0.011 & 0.073 & 0.047 & 0.048 \\
\hline
\end{tabular}


The results of the second stage Fama and Macbeth (1973) cross sectional regression are shown in Table 2. In the first step, time variant slopes are calculated on the 36-month pass returns in rolling windows for each month sorted portfolios. Then these slopes are employed to the calculation of the second stage cross sectional regression while taking the cross sectional returns as dependent variables. The results verify the basic risk and return of a positive relationship between returns and the all risks premiums. Global risk premium captured the additional risk premium that one demand for investing in the foreign country which has a higher risk than the local risk premium. This risk is significant only in the India, and insignificant in all other countries. The results Jethwani and Ramchandani (2020) are also the same for India.

Emerging risk premium is the extra return for investing in the emerging countries which may be under a higher risk than the developed countries. This risk is significant for the Pakistan and South Africa at 5\% while for India, It is significant at 10\%. Industry risk premium is the extra return that one can claim for investment in the specific industry which may have a higher risk than the others. Industry risk premium is significant for Pakistan, India and Brazil. This industry risk factor is significant mostly in those countries where the business structure mostly based on the family owned ownership i.e. Pakistan, India, and Brazil, while this factor is insignificant where business structure is other than that. These results indicate that industry risk premium is an important risk factor to price in the estimation of the cost of equity in those countries where the business structure is built on the family dimensions.

\section{CONCLUSION}

This study extended hybrid CAPM model by incorporating the industrial risk premium. This hybrid CAPM model use the same methodology for model development as used by Bodnar et al. (2004) on the partial integration condition of the economy by adding different risk premium for the estimation of the cost of equity. The researcher empirically tested the inclusion of industry risk premium into the hybrid CAPM as an extra risk premium. Industry risk premium had been calculated by taking difference of continuous industrial returns and local 3 months treasury bills rates. The results of the 
second stage Fama and Macbeth (1973) regression designate that industry risk premium has significance in only those countries where the business is mostly managed by the family owned firms like Pakistan, India and Brazil.

The findings of the study also imply that industry risk premium may be used to capture the agency problems between the monitory and majority shareholders in such business environment, thus reducing agency costs. Based upon the empirical values of statistical and econometric tests, this study supports the fact that market participants may use multifactor CAPM including the industry risk premium while calculating their cost of equity, and they also consider it as sixth factor even if they are using multifactor CAPM. Thus, the research can be considered as an augmentation to the existing multifactor models which can be tested across multiple markets. Future work can be done using the idea of studying the industrial tail exposure risk in line of Liow and Song (2020).

\section{REFERENCES}

Abuaf, N. (2011). Valuing Emerging Market Equities - The Empirical Evidence. Journal of Applied Finance, 21(2), 123-141.

Barad, M. W. (2011). Capturing Industry Risk Within Cost of Capital Analysis. Business Valuation Update, 1-5.

Barinov, A., Xu, J., \& Pottier, S. W. (2020). Estimating the Cost of Equity Capital for Insurance Firms With Multiperiod Asset Pricing Models. Journal of Risk and Insurance, 87(1), 213-245. doi:10.1111/jori.12267

Bawa, V. S., \& Lindenberg, E. B. (1977). Capital market equilibrium in a mean-lower partial moment framework. Journal of Financial Economics. doi:10.1016/0304405X(77)90017-4

Bekaert, G., Harvey, C. R., Lundblad, C., \& Siegel, S. (2016). Political risk and international valuation. Journal of Corporate Finance, 37, 1-23. Retrieved from http://stevenhendrix.com/yahoo_site_admin/assets/docs/Wisc_Intl_Trade_Political_Risk.103143045.pdf

Black, F., Jensen, M. C., \& Scholes, M. (1972). The Capital Asset Pricing Model: Some Empirical Tests (Vol. 81).

Bodnar, G. M., Dumas, B., \& Marston, R. (2004). Cross-border valuation: The international cost of equity capital.

Cederburg, S., \& O'Doherty, M. S. (2016). Does It Pay to Bet Against Beta? On the Conditional Performance of the Beta Anomaly. Journal of Finance, 71(2), 737774. doi:10.1111/jofi.12383

Douglus, G. W. (1968). Risk in the Equity Market: Application of Market Efficiency. Yale Economic Essays, 9, 3-45.

Erb, C. B., Harvey, C. R., \& Viskanta, T. E. (1998). Country risk in the global financial management. Research Foundation Books(1), 1-93.

ES, D., \& Antony, J. (2020). Is CAPM Still Alive for Sensex Stocks in Indian Stock 
Market?-an Empirical Analysis. International Journal of Management, 11(4).

Estrada, J. (2002). Systematic risk in emerging markets: The D-CAPM. Emerging Markets Review, 3(4), 365-379. doi:10.1016/S1566-0141(02)00042-0

Fama, E. F., \& French, K. R. (1992). The Cross-Section of Expected Stock Returns. The Journal of Finance, 47(2), 427-465. doi:10.1111/j.1540-6261.1992.tb04398.x

Fama, E. F., \& Macbeth, J. D. (1973). Risk, Return, and Equilibrium : Empirical Tests. The Univversity of Chicago Press Journals, 81(3), 607-636.

Godfrey, S., \& Espinosa, R. (1996). A Practical Approach to Calculating Costs of Equity for Investments in Emerging Markets. Journal of Financial Economics, 9(3), 8089. doi:10.1111/j.1745-6622.1996.tb00300.x

Harlow, W. V. (1991). Asset Allocation in a Downside-Risk Framework. Financial Analysts Journal, 47(5), 28-40. doi:10.2469/faj.v47.n5.28

Hogan, W. W., \& Warren, J. M. (1974). Toward the Development of an Equilibrium Capital-Market Model Based on Semivariance. The Journal of Financial and Quantitative Analysis, 9(1), 1-1. doi:10.2307/2329964

Hollstein, F., Prokopczuk, M., \& Wese Simen, C. (2020). The Conditional Capital Asset Pricing Model Revisited: Evidence from High-Frequency Betas. Management Science. doi:10.1287/mnsc.2019.3317

Jethwani, K., \& Ramchandani, K. (2020). An Application of CAPM on selected stocks of CNX Nifty 50. Studies in Indian Place Names, 40(8), 163-177.

Jones, J. J. (1991). Earnings Management During Import Relief Investigations. Journal of Accounting Research, 29(2), 193-193. doi:10.2307/2491047

Kayo, E. K., Martelanc, R., Brunaldi, E. O., \& da Silva, W. E. (2020). Capital asset pricing model, beta stability, and the pricing puzzle of electricity transmission in Brazil. Energy Policy. doi:10.1016/j.enpol.2020.111485

Lee, C., Ng, D., \& Swaminathan, B. (2003). International Asset Pricing: Evidence from the Cross Section of Implied Cost of Capital. Working Paper, Barclays Global Investors. Retrieved from http://ssrn.com/abstract=485762

Lessard, D. R. (1996). Incorporating Country Risk in the Valuation of Offshore Projects. Journal of Applied Corporate Finance, 9(3), 52-63. Retrieved from https://onlinelibrary.wiley.com/doi/abs/10.1111/j.1745-6622.1996.tb00298.x

Liow, K. H., \& Song, J. S. (2020). Industrial Tail Exposure Risk and Cross-Section of Returns in REIT Market. SSRN Electronic Journal. doi:10.2139/ssrn.3528950

Mariscal, J., \& Lee, R. (1993). The valuation of Mexican stocks: An extension of the capital asset pricing model. Goldman Sachs, New York. Goldman Sachs, New York.

Musawa, N., Kapena, S., \& Shikaputo, C. (2020). A better stock pricing model: A systematic literature review. Journal of Economic and Financial Sciences, 13(1), $1-6$.

Pei, G. (2019). Empirical Study on the Listed Banks of China: Based on the CAPM Model. Paper presented at the 2019 International Conference on Intelligent Transportation, Big Data \& Smart City (ICITBS).

Pereiro, L. E. (2001). The valuation of closely-held companies in Latin America (Vol. 2).

Perold, A. F. (2004). The Capital Asset Pricing Model. Journal of Economic Perspectives, 18(3), 3-24. doi:10.1257/0895330042162340

Rashid, A., \& Hamid, F. (2015). Downside risk analysis of returns on the Karachi Stock Exchange. Managerial Finance, 41(9), 940-957. doi:10.1108/MF-09-2014-0245

Sharpe, W. F. (1964). Capital asset prices: A theory of Market Equilibrium under Conditions of Risk. The Journal of Finance, 19(3), 425-442. doi:10.2307/2329297 
Škrinjarić, T., \& Slišković, M. (2020). Revisiting the CAPM model with quantile regression: creating investment strategies on the Zagreb Stock Exchange. International Journal of Economics and Business Research, 19(3), 266-289.

Solinik, B. H. (1974). The International Pricing of Risk : An Empirical Investigation of the World Capital Market Structure. Journal of Finance, 29(2), pp365-378.

Stulz, R. M. (1995). GLOBALIZATION OF CAPITAL MARKETS AND THE COST OF CAPITAL : The Case of Nestle. Journal of Applied Corporate Finance, 1(1), 1122.

Urom, C., Chevallier, J., \& Zhu, B. (2020). A dynamic conditional regime-switching GARCH CAPM for energy and financial markets. Energy Economics, 85, 104577. 